\title{
The Effects of Vagal Nerve Stimulation in Focal Cerebral Ischemia and Reperfusion Model
}

\section{Fokal Iskemi ve Reperfüzyon Modelinde Vagal Sinir Uyarnsnnn Etkisi}

Fatih EKICI ${ }^{1}$, Ayse KARSON ${ }^{2}$, Meltem Ozden DILLIOGLUGIL ${ }^{3}$, Gonul GUROL ${ }^{4}$, Hale Maral KIR ${ }^{3}$, Nurbay ATES ${ }^{1}$

${ }^{1}$ Yildirim Beyazit University, Faculty of Medicine, Department of Physiology, Ankara, Turkey

${ }^{2}$ Kocaeli University, Faculty of Medicine, Department of Physiology, Kocaeli, Turkey

${ }^{3}$ Kocaeli University, Faculty of Medicine, Department of Biochemistry, Kocaeli, Turkey

${ }^{4}$ Sakarya University, Faculty of Medicine, Department of Physiology, Sakarya, Turkey

Corresponding Author: Ayse KARSON / E-mail: karson.ayse@gmail.com

\begin{abstract}
AIM: This study aimed to investigate the effects of VNS in transient middle cerebral artery occlusion and reperfusion (MCAO/R) rat model of ischemia based on behavioral, morphological, and molecular approaches.

MATERIAL and METHODS: Wistar albino rats were divided into 3 groups: ischemia-reperfusion (I/R), I/R+VNS, and sham (for I/R). Each group was further divided into two subgroups for the assessment of neurological deficits and infarct area, or biochemical parameters related to oxidative stress.

RESULTS: The infarct area and neurological scores were significantly lower in I/R+VNS group compared with the I/R group. MDA levels were significantly higher in I/R group compared to control and I/R+VNS groups in the cortical and subcortical specimens. There were also betweengroup differences in terms of GSH levels. GSH levels were higher in sham group compared with and I/R and I/R+VNS groups in cortical specimens whereas these levels for lower in I/R group compared to control and I/R+VNS groups in the subcortical specimens. SOD activity was higher in control group compared to I/R and I/R+VNS groups both in the cortical and subcortical specimens. There was no difference between $\mathrm{I} / \mathrm{R}$ and $\mathrm{I} / \mathrm{R}+\mathrm{VNS}$ groups in neither cortical nor subcortical specimens.
\end{abstract}

CONCLUSION: The neuroprotective and antioxidant properties of VNS suggest its efficacy as a potential anti-ischemic treatment.

KEYWORDS: VNS, Focal cerebral ischemia, GSH, MDA, SOD, TTC

Öz

AMAÇ: Bu çalışmada, sıçanlarda geçici orta serebral arterin oklüzyon (OSAo) modelinde vagus sinir uyarısının (VSU) etkilerini, davranışsal, morfolojik ve moleküler yaklaşımlar temelinde araştırmayı amaçladık.

YÖNTEM ve GEREÇLER: Wistar Albino sıçanlar 3 gruba ayrıldı: iskemi reperfüzyon (I/R), sham (I/R için) ve l/R+VSU. Her bir grup kendi içinde nörolojik defisit ve infarkt alan ya da oksidatif stres ile ilişkili biyokimyasal parametreler değerlendirmek üzere iki alt gruba ayrıldı.

BULGULAR: I/R grubuyla karşılaştıııldığında infarkt alanı ve nörolojik defisit skoru I/R+VSU grupta anlamlı şekilde düşüktü. MDA düzeyleri, kortikal ve subkortikal örneklerde I/R+VUS ve kontrol gruplarına göre I/R grubunda anlamlı şekilde yüksek bulundu. GSH düzeyleri açısından da gruplar arasında anlamlı fark vardı. GSH düzeyleri, kortikal örneklerde, sham grupta I/R ve I/R+VUS gruplarına göre yüksek iken, subkortikal örneklerde I/R grupta kontrol ve I/R+VUS gruplarına göre düşüktü. SOD aktivitesi, kortikal ve subkortikal örneklerde kontrol gruplarında I/R $\mathrm{l} / \mathrm{R}+\mathrm{VUS}$ gruplarına göre yüksek bulundu.

SONUÇ: Vagal sinir uyarııının nöron koruyucu ve antioksidan özelliği iskemi tedavisinde potansiyel etkinliğini göstermektedir.

ANAHTAR SÖZCÜKLER: VNS, Bölgesel beyin iskemisi, GSH, MDA, SOD,TTC

\section{INTRODUCTION}

Cerebral ischemic damage is underlain by highly intermingled and complex mechanisms that consist of reduced ATP level, mitochondrial dysfunction, disruption of ion homeostasis, excitotoxicity, free radical generation, inflammation, endothelial dysfunction and necrosis/ apoptosis (25, 31, $44,45)$. Although, reperfusion has been primarily targeted for the specific treatment of acute ischemic stroke $(7,24)$, it causes additional pathological processes, which motivate investigation of new therapeutic approaches $(7,19,24,35,44$, 52).

Free radical generation and the subsequent lipid peroxidation are considered major contributors to the neuronal damage in ischemia and reperfusion $(16,17,18,19)$. Formation of free radicals is an essential destructive factor in the ischemia and reperfusion. Specifically, reperfusion is claimed to trigger the oxidative process $(7,15)$ that is interlinked with other pathological events such as excitotoxicity, mitochondrial 
dysfunction, and inflammation $(4,51)$. The brain is particularly vulnerable to oxidative stress because of higher content of PUFA that are susceptible to lipid peroxidation (1). Under physiological conditions, free radicals are detoxified by endogenous antioxidant enzymes and molecules such as superoxide dismutase (SOD), catalase (CAT), glutathione peroxidase (GPX), glutathione (GSH), alpha-tocopherol, and ascorbate $(1,2,35,46)$. However these defense systems are not sufficient in neutralizing the free radicals in pathological conditions including ischemia $(2,46)$. Therefore, in addition to reperfusion, antioxidant approaches might be effective tools in cerebral ischemia.

Vagus nerve stimulation (VNS) is an adjunctive treatment for certain types of intractable epilepsy and depression (23, 53,42 ). Recent studies have demonstrated the protective effect of VNS in different ischemia models in different organ systems $(5,6,11,14,27)$. We investigated the effects of VNS in ischemia-reperfusion injury by measuring infarct area, and neurological scores. Considering that oxidative stress is a major detrimental process in the pathogenesis of ischemia and reperfusion, we analyzed also oxidative stress markers.

\section{MATERIAL and METHODS}

\section{Animals and Experimental Protocol}

Animal care was provided under the direction of the Animal Care and Use Committee at Kocaeli University. Male Wistar albino rats, weighing 200-300 g, were used. Animals were housed at temperature of $25 \pm 2{ }^{\circ} \mathrm{C}$ with 12 -h light/dark cycle. Rats had free access to standard food pellets and water throughout the study.

Rats were divided randomly into three groups: ischemiareperfusion (I/R), sham (control for $\mathrm{I} / \mathrm{R}$ ), and $\mathrm{I} / \mathrm{R}+\mathrm{VNS}$. Each group was further divided into two subgroups for the assessment of neurological deficits and infarct area or biochemical studies (MDA, SOD and GSH). Rats in the first group were evaluated for neurological scoring 24 hours after MCAO and then sacrificed for TTC staining ( $n=7$ for $\mathrm{l} / \mathrm{R}$ and $\mathrm{I} /$ $\mathrm{R}+\mathrm{VNS}$ groups). Rats in the second group were sacrificed for the biochemical analysis at the $30^{\text {th }}$ minute of reperfusion or sham operation ( $n=7$ for each groups).

\section{Surgical Procedures}

All surgical procedures were performed under diethylether anesthesia. Respiration was inspected throughout the surgical procedure. Rectal core temperature was maintained at $37 \pm 1^{\circ} \mathrm{C}$ with a feedback-regulated heating pad during the operation. Consistent with earlier investigations $(5,20,43)$, and in order to avoid severe invasive procedures, physiological parameters were limited to body temperature and respiration.

\section{Implantation of VNS device and stimulus parameter}

After ventral midline incision on the neck, the skin and muscles were retracted and the left carotid artery was identified. The left cervical vagus nerve was dissected from the carotid artery and spiral stimulation electrodes were wrapped around the nerve under microscopic control. The VNS therapy pulse generator NCP (Neuro Cybernetic Prosthesis) Model 102 (Cyberonics, Inc.; Houston, Texas) was implanted in a subcutaneous pocket on the back of the rats. Twenty-four hours after the surgery, VNS was initiated for the rats that were assigned to the VNS stimulation group.

Electrical stimulation to the left vagus was initiated 10 minutes before the MCA occlusion and continued during the first 30 minutes of reperfusion. The VNS system was programmed using the following parameters: current amplitude of $1 \mathrm{~mA}$, frequency of $20 \mathrm{~Hz}, 12$ second of off-battery time, 30 seconds of on-battery time, and pulse width of $500 \mu \mathrm{s}$.

\section{Middle cerebral artery occlusion}

Reversible middle cerebral artery occlusion was performed as described by Longa et al (1983) (32). A 4-0 silicone coated polypropylene monofilament surgical suture was introduced into the right internal carotid artery (ICA) via the external carotid artery (ECA). The common carotid artery and ICA were temporarily clipped and the suture was placed into the ECA stump, threaded into the ICA with the ICA clip removed, and gently advanced $18 \mathrm{~mm}$ until resistance was felt. The suture was left in place for 90 minutes. Cerebral blood flow was then recovered by slowly withdrawing the suture.

\section{Evaluation of Behavioral, Macroscopic and Biochemical Parameters}

\section{Neurological scoring}

Neurological scoring was performed as described in Longa et al (32); 0: normal, 1: insufficiency in left paw movements, 2: turning to the left side, 3: collapse to left side, 4: deficiency in spontaneous walking.

\section{Evaluation of ischemic area by TTC staining}

The ischemic area was evaluated using TTC staining. Brains were removed and cut into 2 -mm coronal slices. Slices were placed in the vital dye 2,3,5-triphenyltetrazolium chloride (TTC, 2\%; Sigma) at $37{ }^{\circ} \mathrm{C}$ in the dark for $30 \mathrm{~min}$ (54). The infarct area in each section outlined in white was measured using image-analysis software (Adobe Photoshop 8.0, USA). Infarction volume was calculated by summing the infarct volume of sequential 2-mm thick sections (28).

\section{Biochemical analysis}

After 90 minute-long middle cerebral ischemia and 30 minute-long reperfusion phase. Rats were decapitated and brain tissues removed quickly. All neocortex and subcortical forebrain structures including the striatum, thalamus and hypothalamus were kept in two different tubes at $-80^{\circ} \mathrm{C}$. Tissue samples were washed with $0.9 \% \mathrm{NaCl}$ solution and were kept in ice during this process. Tissues were homogenized with $0.1 \mathrm{M}$ phosphate buffer $(\mathrm{pH} 7.4)$ until no tissue particle was observed. Tissue lipid peroxidation levels of MDA were measured as described in Buege and Aust (1978) and results were reported in terms of $\eta \mathrm{mol} / 100 \mathrm{mg}$ protein (13). GSH levels were measured with 5, 5'-dithiobis-(2-nitrobenzoate) 
at $412 \mathrm{~nm}$ according to the Elman method and results were reported in terms of $\mathrm{nmol} / \mathrm{mg}$ protein (21). The activity of CuZn SOD was calculated kinetically as described in Sun et al. (47) and results were reported in terms of $U / \mathrm{mg}$. The protein concentrations of tissue homogenates were established as described in Lowry et al. (33).

\section{Statistical Analysis}

Statistical analyses were performed using Prism 5.0 (GraphPad Software Inc.). Data were expressed as mean \pm SEM. Differences between (I/R and I/R+VNS) groups were determined using Student's t-test for infarct volume and neurological score. Biochemical markers were compared using one-way analysis of variance (ANOVA) followed by posthoc Newman-Keuls tests. Alpha level of 0.05 was used for all inferential statistics.

$\mathrm{I} / \mathrm{R}$

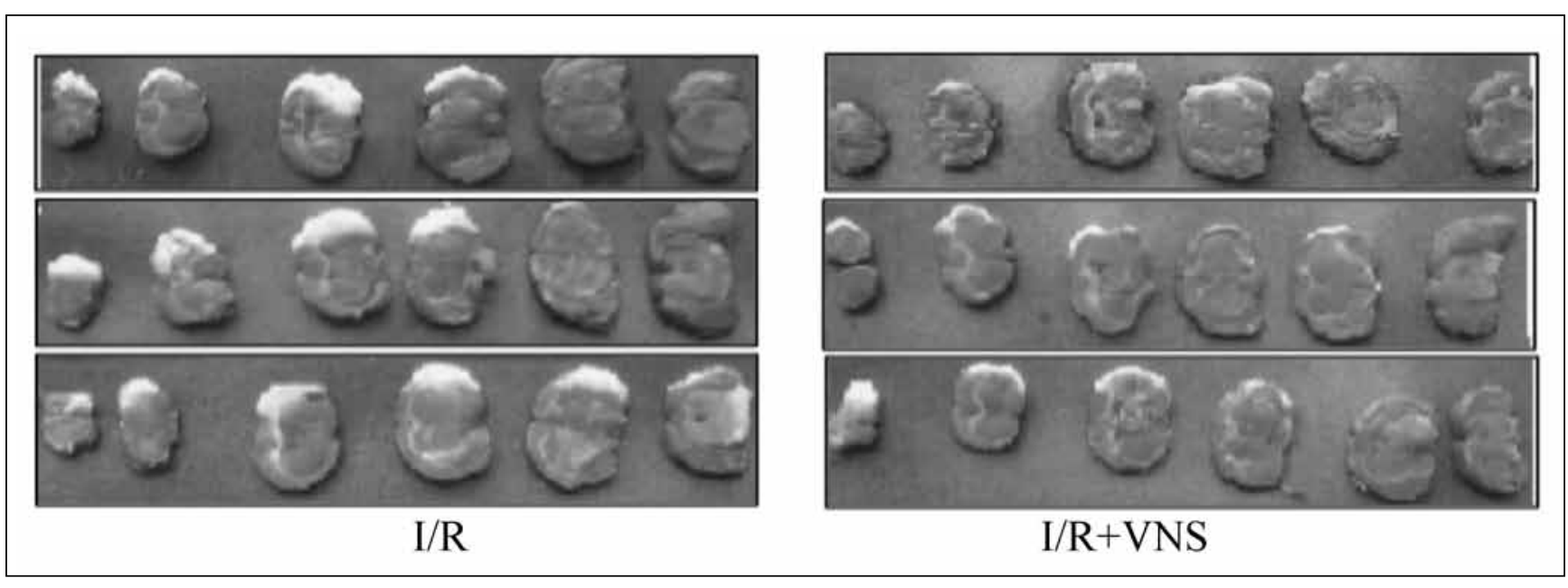

\section{RESULTS}

\section{Infarct Area and Neurological Scores}

The ratio of infarct area to the same hemisphere was $16.22 \%$ \pm 1.38 in the $\mathrm{l} / \mathrm{R}$ group and $8.77 \% \pm 0.88$ in the $\mathrm{I} / \mathrm{R}+\mathrm{VNS}$ group. The infarct area in I/R+VNS group was significantly lower than it was in the I/R group $(t(12)=4.55, p<0.001)$. There was over $45 \%$ reduction in the infarct area with the application of VNS treatment (Figure 1, 2A).

Neurological scores were $2.42 \pm 0.2$ for the I/R group and 1.28 \pm 0.18 for the $\mathrm{I} / \mathrm{R}+\mathrm{VNS}$ group. VNS group neurological scores were statistically lower compared to I/R group $(t(12)=4,23$, $p<0.01$ ) (Figure 2B).

\section{Biochemical Analysis of Oxidative Stress}

Brain tissues were evaluated separately as cortical and subcortical samples.

Figure 1: Representative images of six slices ( $2 \mathrm{~mm}$ thick) of rat brain $24 \mathrm{~h}$ after MCAO/R of I/R and l/R+VNS groups. Infarct area appears as a white region in the slices incubated in TTC.

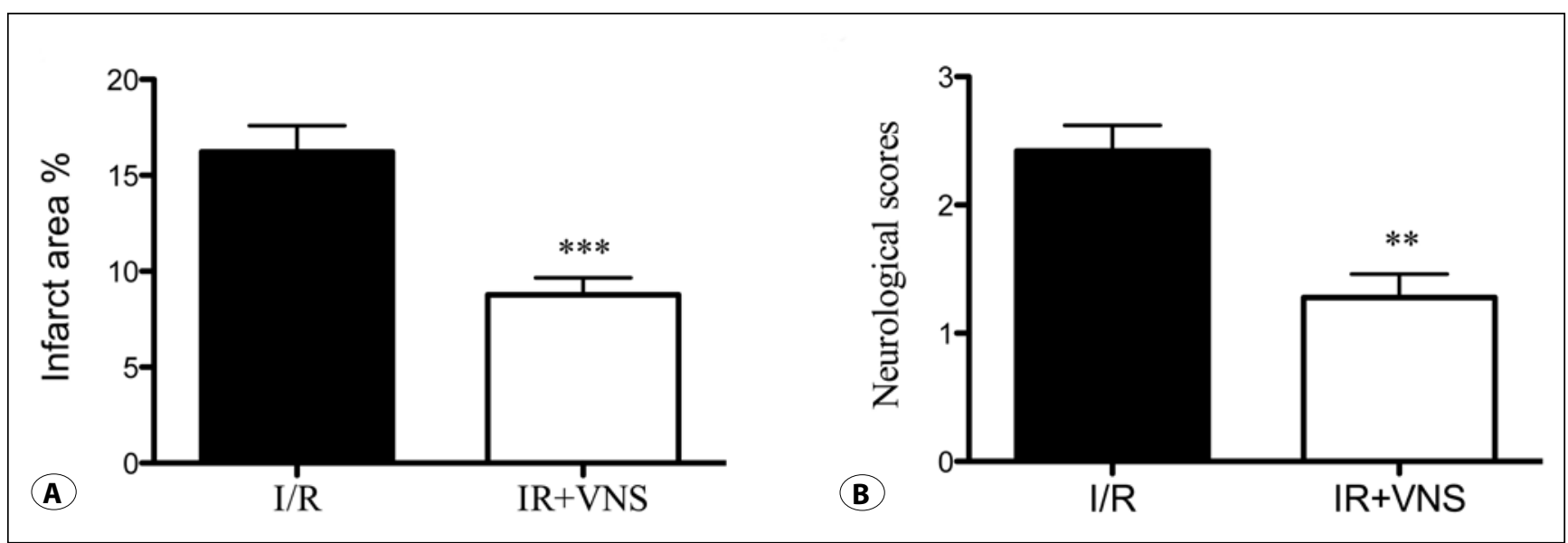

Figure 2: Infarct area and neurological scores of I/R and I/R+VNS groups. (A) The percentages of infarct area were significantly lower in I/R+VNS group compared to I/R group. (B) VNS group showed a significant reduction of neurological deficit score 24 hours after $\mathrm{MCAO} / \mathrm{R}$ compared to I/R group. Data were expressed as the mean $\pm \operatorname{SEM}\left({ }^{* *} p<0.01{ }^{* * *} p<0.001\right)$. 


\section{MDA levels}

For cortical specimens, average MDA (nmol/100mg protein) levels were $1.6 \pm 0.14$ for control, $11.51 \pm 3.59$ for $\mathrm{l} / \mathrm{R}$, and $1.85 \pm$ 0.32 for $1 / R+V N S$ groups. For subcortical specimens, these levels were $1.64 \pm 0.16,3.93 \pm 0.73,1.95 \pm 0.44$, respectively. There was a significant overall difference between three groups in terms of the MDA content of cortical and subcortical samples, $F(2,18)=7.36, p<0.01$ and $F(2,18)=6.15, p<0.01$, respectively. Post-hoc comparisons revealed significant increases in MDA level of the I/R group compared to control and $\mathrm{I} / \mathrm{R}+\mathrm{VNS}$ groups (both $p s<0.01$ ) in cortical specimens, and I/R group compared to control $(p<0.05)$ and I/R+VNS groups $(p<0.05)$ in subcortical specimens (Figure 3A).

\section{GSH levels}

In cortical specimens, GSH (nmol/mg protein) levels were $37.96 \pm 6.16$ for control, $6.85 \pm 1.38$ for $I / R$, and $20.7 \pm 3.9$ for $\mathrm{I} / \mathrm{R}+\mathrm{VNS}$ groups. In subcortical specimens, these levels were $36.19 \pm 6.07,7.16 \pm 1.35$, and $18.02 \pm 3.95$, respectively. There was a significant overall difference between three groups in terms of the GSH content of the cortical and subcortical samples, $F(2,18)=13.24, p<0.001$ and $F(2,18)=11.89, p<0.001$, respectively. Post-hoc comparisons revealed significant difference in GSH levels between control and I/R $(p<0.001)$, $\mathrm{I} / \mathrm{R}$ and $\mathrm{I} / \mathrm{R}+\mathrm{VNS}(p<0.05)$, and control and I/R+VNS $(p<0.05)$ groups in cortical specimens (Figure $3 \mathrm{~B}$ ). There were also significant differences between I/R vs. control $(p<0.001)$ and I/R vs. I/R+VNS groups $(p<0.01)$ in subcortical specimens (Figure 3B).

\section{SOD activity}

In cortical specimens, the level of $\mathrm{Cu}-\mathrm{Zn}$ SOD (U/mg protein) activity was $11.64 \pm 3.07$ for control, $3.12 \pm 0.37$ for $\mathrm{l} / \mathrm{R}$, and $5.5 \pm 0.57$ for $\mathrm{l} / \mathrm{R}+\mathrm{VNS}$ groups. In subcortical specimens, these levels were $12.83 \pm 2.80,2.94 \pm 0.30$, and $6.64 \pm 0.59$, respectively. There was a significant overall difference between three groups in terms of SOD activity levels in cortical and subcortical samples, $F(2,18)=5.86, p<0.05$ and $F(2,18)=6.15, p<0.01$, respectively. Post-hoc comparisons revealed significantly higher SOD activity level for the control group compared to I/R $(p<0.05)$ and I/R+VNS groups $(p<0.05)$ in cortical specimens. In subcortical specimens, SOD activity level was higher for the control group compared to $\mathrm{I} / \mathrm{R}(p<0.01)$ and $\mathrm{I} / \mathrm{R}+\mathrm{VNS}$ groups $(p<0.05)$. There was no difference between $\mathrm{I} / \mathrm{R}$ and $\mathrm{I} / \mathrm{R}+\mathrm{VNS}$ groups in either cortical or subcortical specimens (Figure $2 \mathrm{C}$ ).

\section{DISCUSSION}

Our results revealed a beneficial effect of VNS against neuronal injury in the rat model of MCAO/R. Neurological examination conducted 24 hours after MCAO/R showed that motor deficits decreased as result of the VNS administration. The neuroprotective effects of VNS treatment were further supported by reduction in the infarct volume as assessed with TTC staining. Regarding the effects of VNS on the oxidative processes, we have established that VNS treatment resulted in a significant decrease in MDA (a lipid peroxidation product) levels in cortical and subcortical homogenates, and a significant increase in GSH levels in cortical homogenates. On the other hand, levels of subcortical GSH and cortical and subcortical SOD activity slightly but insignificantly increased. The antioxidant effect of VNS in focal cerebral I/R has been demonstrated for first time in this study.

Previous investigation of the effect of VNS on global cerebral ischemia in gerbils revealed a decrease in cell death in the hippocampus $(37,38)$. Recently, Ay and colleagues showed that ischemic lesion volume was smaller in VNS-treated compared to control animals (5). Follow-up studies further established that this effect of VNS was not due to the cerebral blood flow changes $(6,27)$, although changes in blood flow have been previously shown in epileptic patients (26). In line with these findings, we found that VNS normalized the neurological scores and reduced the infract volume. Decreased MDA and increased GSH content of the brain with VNS further pointed at its potential efficacy against free radical generation and lipid peroxidation. The first of these molecules is considered to be a reliable indicator of lipid peroxidation that constitutes the primary destructive process in oxidative stress $(15,46)$. The second one is a powerful antioxidant, which is involved in the endogenous defense system of tissues against reactive oxygen species (46). The antioxidant properties of VNS becomes even more crucial, given the fact that free radicals disrupt the brain-blood barrier by injuring the cerebral endothelial cells and play a primary role in the formation of inflammation, which leads to worsening of the ischemic tissue $(12,30)$.

One of our findings that appears to contradict with the antioxidant property of VNS is that SOD levels decreased in the IR group, however increased only slightly (nonsignificantly) in the IR+VNS group. The SOD enzyme that is typically known for its antioxidant effects can also exert oxidant effects depending on other factors $(2,15,40)$. SOD detoxifies superoxide radical $\left(\mathrm{O}_{2}^{-}\right)$to hydrogen peroxide $\left(\mathrm{H}_{2} \mathrm{O}_{2}\right)$, which is further converted to $\mathrm{H}_{2} \mathrm{O}$ via catalase and/ or glutathion peroxidase (by oxidation of GSH) enzymes. Therefore, SOD activity could prevent $\mathrm{O}_{2}$-related processes including the formation of peroxynitrite, another oxidative radical produced as a consequence of $\mathrm{O}_{2}$ and nitric oxide (NO) reaction. On the other hand, in the presence of free metals (i.e. $\mathrm{Fe}+2$ ), $\mathrm{H}_{2} \mathrm{O}_{2}$ might be a source of hydroxyl radicals $(\mathrm{OH}-)$, especially in case of insufficient catalase enzyme. $\mathrm{OH}$ - is known to be the most harmful of all reactive oxygen species (ROS) that causes cell injury through reacting with lipids, proteins, and nucleic acids. Consequently, the limited rather than excessive increase in SOD activity may exert a beneficial effect in oxidative injury.

The agents/treatments that have antioxidant properties might exert their effects via various routes such as preventing the causative mechanisms, directly interacting with reactive molecules or modulating the antioxidant defense systems. VNS is currently used in treatment-resistant epilepsies and 


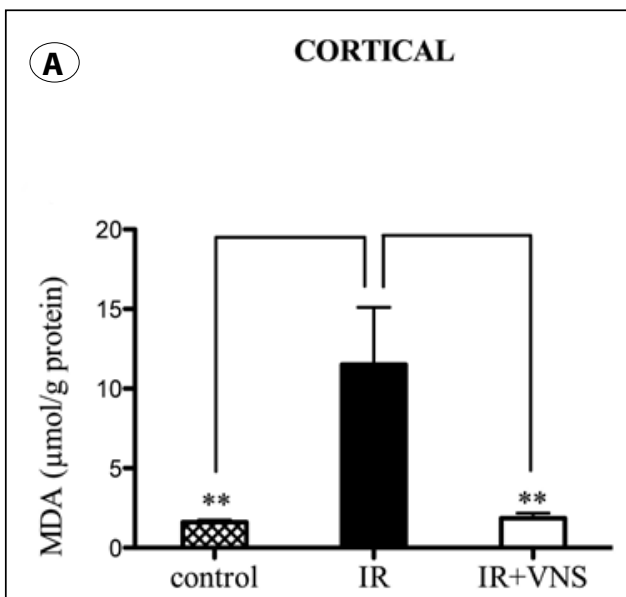

(B)

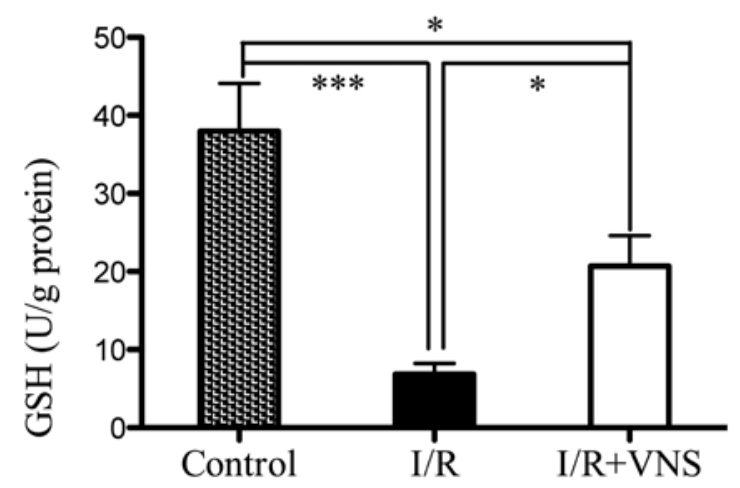

(c)

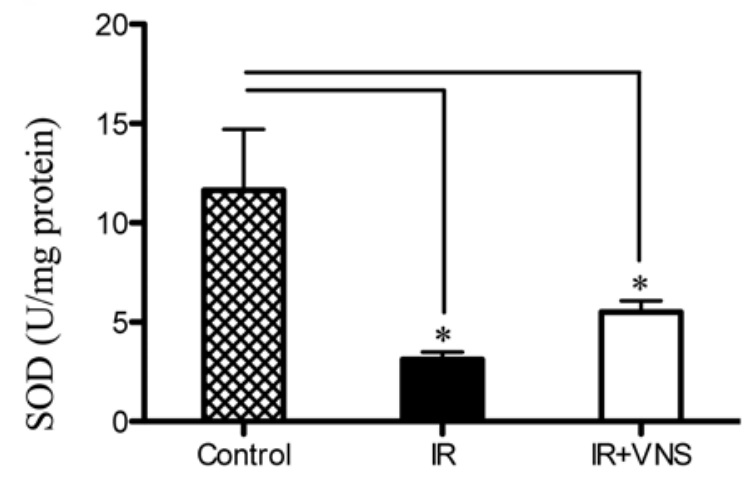

SUBCORTICAL
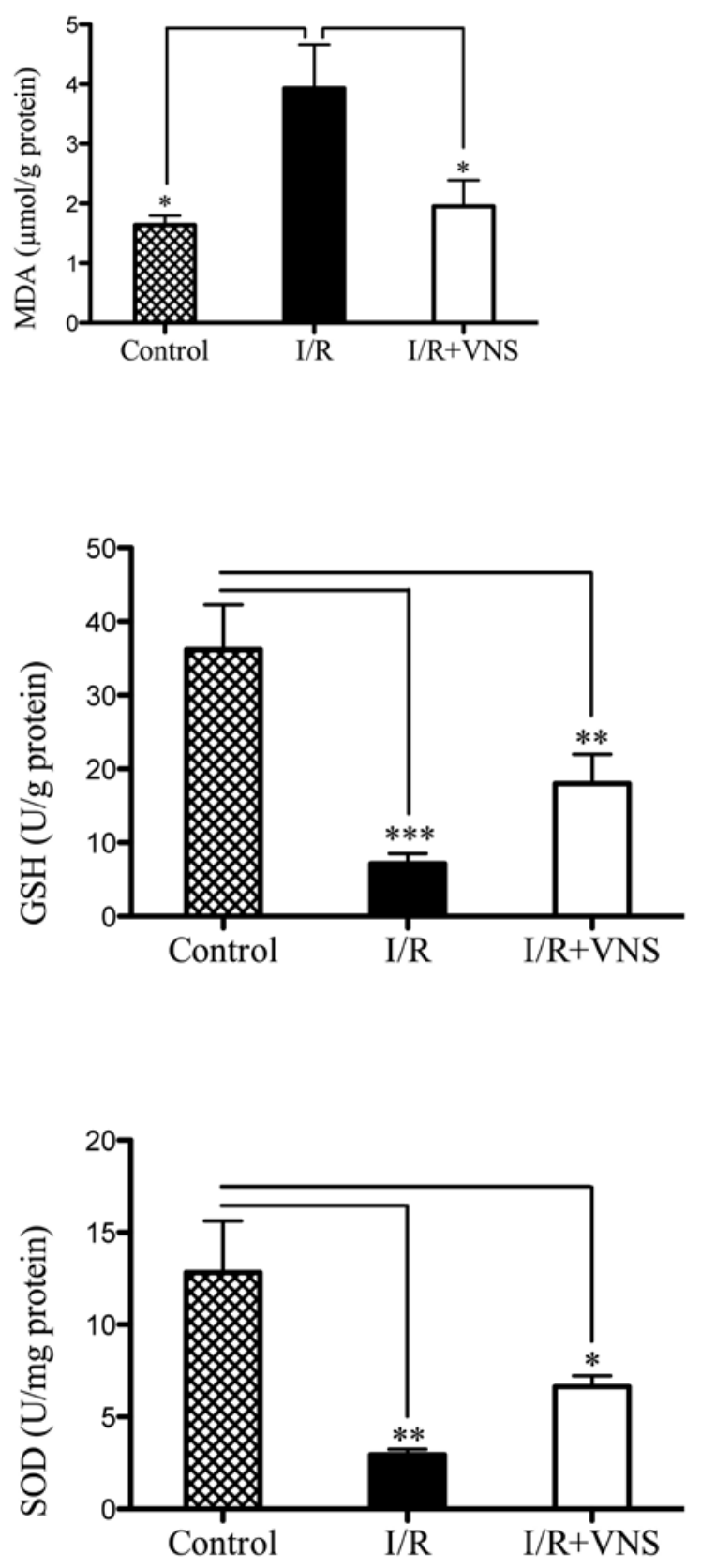

Figure 3: A) MDA levels, B) GSH levels, and C) SOD activity separately for cortical and subcortical specimens and control, I/R, and I/ R+VNS groups. (A) MDA levels were higher in I/R group compared to control and I/R+VNS groups in both specimens (B) GSH levels were in I/R group compared to control and I/R+VNS groups in both specimens. In cortical specimens, GSH levels were higher in I/ R+VNS group compared to I/R group. GSH levels of I/R+VNS group were also lower than control group in cortical and subcortical specimens. (C) SOD activity was lower in I/R group compared to control group in the both cortical and subcortical specimens. Despite, slightly higher SOD activity of I/R+VNS compared to I/R group, this increase was not statistically significant. Data were expressed as the mean $\pm \operatorname{SEM}\left({ }^{*} p<0.05,{ }^{* *} p<0.01,{ }^{* * *} p<0.001\right)$. 
depression $(20,23,42)$. It was found to increase GABAergic and decrease glutamatergic activity in the brain $(8,10,36$, 39). These mechanisms might mediate the effects of VNS in reducing the excitotoxicity and related reduction in the formation of free radicals or vice versa. Another possible factor that might mediate the antioxidant and neuroprotective effect of VNS is its anti-inflammatory properties. Recent studies reported the inhibitory effect of VNS on the proinflammatory cytokine (e.g., TNFa) secretion $(9,29,34,50)$. It was shown that proinflammatory cytokines are activated soon after cerebral ischemia $(22,48,49)$ and that these lead to both inflammatory reaction and formation of free radicals (2, 41). Thus, the inhibition of inflammatory cytokines with VNS might contribute to the reduction of ischemic injury.

We conclude that VNS has a neuroprotective and antioxidant efficacy in the focal cerebral ischemia and reperfusion. Together with recent reports, our results suggest that VNS or other applications modulating the functions of vagus nerve can be considered as a promising new alternative treatment for cerebral ischemic injury. The potential role of VNS in different neuropathological conditions related to oxidative stress requires further investigation.

\section{ACKNOWLEDGMENTS}

We would like to thank Dr. Fuat Balc for his valuable input on earlier drafts of this manuscript.

\section{REFERENCES}

1. Adibhatla RM, Hatcher JF: Lipid oxidation and peroxidation in CNS health and disease: From molecular mechanisms to therapeutic opportunities. Antioxid Redox Signal 12:125-169, 2010

2. Aguiar CC, Almeida AB, Araújo PV, de Abreu RN, Chaves EM, do Vale OC, Macêdo DS, Woods DJ, Fonteles MM, Vasconcelos SM: Oxidative stress and epilepsy: Literature review. Oxid Med Cell Longev 2012:795259, 2012

3. Amantea D, Nappi G, Bernardi G, Bagetta G, Corasaniti MT: Post-ischemic brain damage: Pathophysiology and role of inflammatory mediators. FEBS J 276:13-26, 2009

4. Andersen JK: Oxidative stress in neurodegeneration: Cause or consequence. Nat Med 10:S18-25, 2004

5. Ay I, Lu J, Ay H, Gregory Sorensen A: Vagus nerve stimulation reduces infarct size in rat focal cerebral ischemia. Neurosci Lett 14:147-151, 2009

6. Ay I, Sorensen AG, Ay $\mathrm{H}$ : Vagus nerve stimulation reduces infarct size in rat focal cerebral ischemia: An unlikely role for cerebral blood flow. Brain Res 25:110-115, 2011

7. Badruddin A, Taqi MA, Abraham MG, Dani D, Zaidat OO: Neurocritical care of a reperfused brain. Curr Neurol Neurosci Rep 11:104-110, 2011

8. Banerjee $\mathrm{S}$ : Effects of vagus nerve stimulation on hippocampal and cortical amino acid levels following lateral fluid percussion injury in rats: A microdialysis study (thesis), Southern Illinois Universty at Carbondale, 2006: 1- 136.
9. Bansal V, Ryu SY, Lopez N, Allexan S, Krzyzaniak M, Eliceiri B, Baird A, Coimbra R:Vagal stimulation modulates inflammation through a ghrelin mediated mechanism in traumatic brain injury. Inflammation 35:214-220, 2012

10. Ben-Menachem E, Hamberger A, Hedner T, Hammond EJ, Uthman BM, Slater J, Treig T, Stefan H, Ramsay RE, Wernicke $\mathrm{JF}$, et al: Effects of vagus nerve stimulation on amino acids and other metabolites in the CSF of patients with partial seizures. Epilepsy Res 20:221-227, 1995

11. Bernik TR, Friedman SG, Ochani M, DiRaimo R, Susarla S, Czura CJ, Tracey KJ: Cholinergic antiinflammatory pathway inhibition of tumor necrosis factor during ischemia reperfusion. J Vasc Surg 36:1231-1236, 2002

12. Brouns R, De Deyn PP: The complexity of neurobiological processes in acute ischemic stroke. Clin Neurol Neurosurg 111:483-495, 2009

13. Buege JA, Aust SD: Microsomal lipid peroxidation. Meth Enzymol 52:302-310, 1978

14. Calvillo L, Vanoli E, Andreoli E, Besana A, Omodeo E, Gnecchi M, Zerbi P, Vago G, Busca G, Schwartz PJ: Vagal stimulation, through its nicotinic action, limits infarct size and the inflammatory response to myocardial ischemia and reperfusion. J Cardiovasc Pharmacol 58:500-507, 2011

15. Chen $H$, Yoshioka H, Kim GS, Jung JE, Okami N, Sakata H, Maier CM, Narasimhan P, Goeders CE, Chan PH: Oxidative stress in ischemic brain damage: Mechanisms of cell death and potential molecular targets for neuroprotection. Antioxid Redox Signal 14(8):1505-1517, 2011

16. Chong ZZ, Kang JQ, Maiese K: Essential cellular regulatory elements of oxidative stress in early and late phases of apoptosis in the central nervous system. Antioxid Redox Signal 6:277-287, 2004

17. Costello DJ, Delanty N: Oxidative injury in epilepsy: Potential for antioxidant therapy. Expert Rev Neurother 4:541-553, 2004

18. Coyle JT, Puttfarcken P: Oxidative stress, glutamate, and neurodegenerative disorders. Science 29(262):689-695, 1993

19. Crack PJ, Taylor JM: Reactive oxygen species and the modulation of stroke. Free Radic Biol Med 38:1433-1444, 2005

20. Cunningham JT, Mifflin SW, Gould GG, Frazer A: Induction of c-Fos and DeltaFosB immunoreactivity in rat brain by Vagal nerve stimulation. Neuropsychopharmacology 33:18841895,2008

21. Ellman GL: Tissue sulfhydryl groups. Arch Biochem Biophys 82: 70-77, 1959

22. Ferrarese $C$, Mascarucci $P$, Zoia C, Cavarretta R, Frigo M, Begni B, Sarinella F, Frattola L, De Simoni MG: Increased cytokine release from peripheral blood cells after acute stroke. J Cereb Blood Flow Metab 19(9):1004-1009, 1999

23. George MS, Nahas Z, Bohning DE, Lomarev M, Denslow S, Osenbach R, Ballenger JC: Vagus nerve stimulation: A new form of therapeutic brain stimulation. CNS Spectr 5:43-52, 2000 
24. Green AR, Shuaib A: Therapeutic strategies for the treatment of stroke. Drug Discov Today 11:681-693, 2006

25. Gupta YK, Chauhan A: Potential of immunosuppressive agents in cerebral ischaemia. Indian J Med Res 133:15-26, 2011

26. Henry TR, Votaw JR, Pennell PB, Epstein CM, Bakay RAE, Faber TL, Grafton ST, Hoffman JM: Acute blood flow changes and efficacy of vagus nerve stimulation in partial epilepsy. Neurology 52:1166-1173, 1999

27. Hiraki T, Baker W, Greenberg JH: Effect of vagus nerve stimulation during transient focal cerebral ischemia on chronic outcome in rats. J Neurosci Res 90:887-894, 2012

28. Khan M, Sakakima H, Dhammu TS, Shunmugavel A, Im YB, Gilg AG, Singh AK, Singh I: S-nitrosoglutathione reduces oxidative injury and promotes mechanisms of neurorepair following traumatic brain injury in rats. J Neuroinflammation 6(8):78, 2011

29. Kong SS, Liu JJ, Hwang TC, Yu XJ, Lu Y, Zang WJ: Tumour necrosis factor- $a$ and its receptors in the beneficial effects of vagal stimulation after myocardial infarction in rats. Clin Exp Pharmacol Physiol 38:300-306, 2011

30. Lehner C, Gehwolf R, Tempfer H, Krizbai I, Hennig B, Bauer HC, Bauer $\mathrm{H}$ : Oxidative stress and blood-brain barrier dysfunction under particular consideration of matrix metalloproteinases. Antioxid Redox Signal 15:1305-1323, 2011

31. Leker RR, Shohami E: Cerebral ischemia and traumadifferent etiologies yet similar mechanisms: Neuroprotective opportunities. Brain Res Rev 39:55-73, 2002

32. Longa EL, Weinstein PR, Carlson S, Commins R: Reversible middle cerebral artery occlusion without craniectomy in rats. Stroke 20:84-91, 1989

33. Lowry $\mathrm{OH}$, Rosebrough NJ, Farr AL, Randall RJ: Protein measurement with the phenol reagent. J Biol Chem 193: 265-275, 1951

34. Majoie HJ, Rijkers K, Berfelo MW, Hulsman JA, Myint A, Schwarz $M$, Vles JS: Vagus nerve stimulation in refractory epilepsy: Effects on pro- and anti-inflammatory cytokines in peripheral blood. Neuroimmunomodulation 18:52-56, 2011

35. Margaill I, Plotkine M, Lerouet D: Antioxidant strategies in the treatment of stroke. Free Radic Biol Med 39:429-443, 2005

36. Marrosu F, Serra A, Maleci A, Puligheddu M, Biggio G, Piga $M$ : Correlation between GABAA receptor density and vagus nerve stimulation in individuals with drug-resistant partial epilepsy. Epilepsy Res 55:59-70, 2003

37. Masada $T$, Itano $T$, Fujisawa $M$, Miyamoto $O, M$ Tokuda $M$, Matsui $\mathrm{H}$, et al.: Protective effect of vagus nerve stimulation on forebrain ischemia in gerbil hippocampus. Neuroreport 7:446-448, 1996

38. Miyamoto O, Pang J, Sumitani K, Negi T, Hayashida Y, Ýtano $\mathrm{T}$ : Mecanisms of the antiischemic effect of vagus nerve stimulation in the gerbil hippocampus. Neuroreport 14: 1971-1974, 2003

39. Neese SL, Sherill LK, Tan AA, Roosevelt RW, Browning RA, Smith DC, Duke A, Clough RW: Vagus nerve stimulation may protect GABAergic neurons following traumatic brain injury in rats: An immunocytochemical study. Brain Res 1128(1):157163,2007
40. Offer T, Russo A, Samuni A: The pro-oxidative activity of SOD and nitroxide SOD mimics. FASEB J 14(9):1215-1223, 2000

41. Pantoni L, Sarti C, Inzitari D: Cytokines and cell adhesion molecules in cerebral ischemia: Experimental bases and therapeutic perspectives. Arterioscler Thromb Vasc Biol 18(4):503-513, 1998

42. Rizvi SJ, Donovan M, Giacobbe P, Placenza F, Rotzinger S, Kennedy SH: Neurostimulation therapies for treatment resistant depression: $A$ focus on vagus nerve stimulation and deep brain stimulation. Int Rev Psychiatry 23:424-436, 2011

43. Sahin D, Ilbay G, Imal M, Bozdogan O, Ates N: Vagus nerve stimulation suppresses generalized seizure activity and seizure-triggered postictal cardiac rhythm changes in rats. Physiol Res 58:345-350, 2009

44. Sahota P, Savitz SI: Investigational therapies for ischemic stroke: Neuroprotection and neurorecovery. Neurotherapeutics 8:434-451, 2011

45. Saito A, Maier CM, Narasimhan P, Nishi T, Song YS, Yu F, Liu J, Lee YS, Nito C, Kamada H, Dodd RL, Hsieh LB, Hassid B, Kim EE, González M, Chan PH: Oxidative stress and neuronal death/ survival signaling in cerebral ischemia. Mol Neurobiol 31: 105-116, 2005

46. Schmidley JW: Free radicals in central nervous system ischemia. Stroke 21:1086-1090, 1990

47. Sun Y, Oberley LW, Li Y: A simple method for clinical assay of superoxide dismutase. Clin Chem 34:497-500, 1988

48. Tarkowski E, Rosengren L, Blomstrand C, Wikkelso" C, Jensen C, Ekholm S, Tarkowski A: Early intrathecal production of interleukin-6 predicts the volume of brain lesion in stroke. Stroke 26:1393-1398, 1995

49. Tarkowski E, Rosengren L, Blomstrand C, Wikkelso“ C, Jensen C, Ekholm S, Tarkowski A: Intrathecal release of pro- and antiinflammatory cytokines during stroke. Clin Exp Immunol 110: 492-499, 1997

50. van Westerloo DJ, Giebelen IA, Meijers JC, Daalhuisen J, de Vos AF, Levi M, van der Poll T: Vagus nerve stimulation inhibits activation of coagulation and fibrinolysis during endotoxemia in rats. J Thromb Haemost 4:1997-2002, 2006

51. Zádori D, Klivényi P, Szalárdy L, Fülöp F, Toldi J, Vécsei L: Mitochondrial disturbances, excitotoxicity, neuroinflammation and kynurenines: Novel therapeutic strategies for neurodegenerative disorders. J Neurol Sci 322(1-2):187-191, 2012

52. Zaleska MM, Mercado ML, Chavez J, Feuerstein GZ, Pangalos MN, Wood A: The development of stroke therapeutics: Promising mechanisms and translational challenges. Neuropharmacology 56:329-341, 2009

53. Zamponi N, Petrelli C, Passamonti C, Moavero R, Curatolo P: Vagus nerve stimulation for refractory epilepsy in tuberous sclerosis. Pediatr Neurol 43:29-34, 2010

54. Zhong P, Pang SF, Cheung RTF: Pretreatment with melatonin reduces volume of cerebral infarction in a rat middle cerebral artery occlusion stroke model. J Pineal Res 32:168-172, 2002 